\title{
Managerialism, Organizational Commitment, and Quality of Job Performances among European University Employees
}

\author{
Sanne Smeenk $\cdot$ Christine Teelken $\cdot$ Rob Eisinga $\cdot$ Hans Doorewaard
}

Received: 12 March 2008/Published online: 7 April 2009

(C) The Author(s) 2009. This article is published with open access at Springerlink.com

\begin{abstract}
To achieve efficient and effective quality improvement, European universities have gradually adopted organizational strategies, structures, technologies, management instruments, and values that are commonly found in the private business sector. Whereas some studies have shown that such managerialism is beneficial to the quality of job performances of university employees, others have argued that managerialism is largely counterproductive and that it results in lower performances. The latter situation is called a 'managerialism contradiction'. This paper tests two lines of reasoning underlying a potential contradiction governing the relationship between managerialism and job performances, while using university employee survey data from six European countries (Belgium, Finland, Germany, Netherlands, Sweden, UK). The results tend to support the assumption that managerialism, in these six countries at least, has a positive effect, albeit a modest one, on the quality of performances. The most important conclusion is therefore that there is no managerialism contradiction at work in European universities.
\end{abstract}

Keywords Managerialism · Organizational commitment - Quality of job performances · University employees

S. Smeenk

Institute for Policy Research, University of Tilburg, Tilburg, The Netherlands

C. Teelken $\cdot$ H. Doorewaard

Institute for Management Research, Radboud University Nijmegen,

P.O. Box 9108, 6500 HK Nijmegen, The Netherlands

C. Teelken ( $\triangle)$

Faculty of Social Sciences, Department of Organisation Science,

VU University Amsterdam, De Boelelaan 1081, 1081 HV Amsterdam, The Netherlands

e-mail: jc.teelken@fsw.vu.nl

R. Eisinga

Nijmegen Institute for Social Cultural Research,

Radboud University Nijmegen, Nijmegen, The Netherlands 


\section{Introduction}

As a result of socio-economic and political developments, such as budget constraints, accountability for quality, 'massification', and decentralization of higher education (e.g., Bryson 2004), universities all over Europe have adopted organizational strategies, structures, technologies, management instruments, and values that are commonly found in the private business sector (Aucoin 1990; Deem 1998). This trend of copying techniques of the private sector by public organizations is "one of the earliest features of New Public Management, and remains one of the most enduring" (Boyne 2002, p. 97) and may even go further back then the actual term 'New Public Management' (NPM) or 'managerialism' (Hood 1991, 1995; Pollitt 1993).

Some researchers suggest that " "some dose' of 'managerialism' in the right proportion and in the right context" may be useful in universities and that it positively affects the quality of job performances (Chan 2001, p. 109; see also RAE (Research Assessment Exercise) 2001). This judgment is challenged by others who argue that managerialism works against its own intentions of efficient and effective quality improvement (see Bryson 2004; Davies and Thomas 2002; Thornhill et al. 1996; Trow 1994b). The latter situation is what we call a 'managerialism contradiction' (Smeenk et al. 2006) and the purpose of this paper is to examine its possible existence by testing two lines of reasoning. In the first one, managerialism is suggested to have a direct effect on the quality of performances ('direct effect argumentation'). The second line of reasoning assumes that managerialism has an indirect effect on the quality of job performances that is mediated by organizational commitment ('indirect effect argumentation'). Whereas most studies on the consequences of managerialism in universities are qualitative in character, we conducted a quantitative empirical study of the issue, using data from a survey carried out among university employees from six European countries.

The paper is organized as follows. In the next section, after discussing the context of this research in terms of 'universities in change', a number of hypotheses are formulated to test the possible existence of a managerialism contradiction. Section "Methods" discusses the methods used for our empirical study. The analyses and findings are presented in the Sect. "Results" and the paper ends with a discussion in the Sect. Discussion and Conclusion.

\section{Universities in Change}

It is generally recognized that universities are among the most stable and change-resistant social institutions in the Western society, considering that their roots go back to medieval times. There is consensus among higher education leaders that the core functions of higher education - to educate (knowledge transfer), to do research (knowledge production) and to provide in community service (outreach, emanating from the knowledge base)—must be preserved, reinforced, and expanded. Although universities are long-standing institutions and maintain an established reputation, they are in the process of transforming both identity and structure.

The transformation of universities cannot be understood in isolation; it is the whole process of knowledge creation that is subject of discussion. Etzkowitz and Leydesdorff 2000 argued in many contributions (e.g., 2000) that the categorization in terms of 'national systems of innovation' (Lundvall 1992; Nelson 1993); 'research systems in transition' (Cozzens et al. 1990), 'the post modern research system' (Rip and Van der Meulen 1996) and the 'Mode 2' thinking (Clark 1998; Gibbons et al. 1994) are indicative of the reorganization of knowledge creation and diffusion in the economy and society. Since the 
1980s, different schools of thought have appeared in public policy, focusing on efficiency and the deficits of the bureaucratic model (Osborne and Gaebler 1992), initially with a heavy emphasis on privatisation and market mechanisms (Clarke and Newman 1997). In our view, public sector governance evolved out of the new public management phenomenon, which has, as Hood et al. (1999, 2000) and others (Dent 2005; Dent et al. 2007) have observed, become increasing preoccupied with surveillance and regulation.

Managerialism as a trend is a relatively recent occurrence in the European higher education. The so-called market-model of higher education, which is considered typical for the North American tradition (Lazzeretti and Tavoletti 2006), was introduced in Europe in the late nineties. In the US, the creation and financial funding of universities was done through external stakeholders, the local community and its representatives. Universities are considered 'individual property' (Neave 2002). This contrasts the continental European tradition where the stakeholders belong to three spheres of negotiation: the government (parliament, ministry of education), the academics and the external bodies. The fundamental distinction between the European and the US tradition of education has influenced the current literature on NPM and managerialism in higher education. Many of the changes which are currently taking place in European higher education systems (such as a hierarchical differentiation of research funding, the increased importance of private funding, and students having to pay a significant share of their tuition) have long been the case in the US (Vincent Lancrin 2007).

The major source for NPM ideas in the 1990s was 'Reinventing Government' by Osborne and Gaebler (1992). Apparently their study achieved a cult status in the US, and their ideas were subsequently distributed across Europe (Saint Martin 2005). Osborne and Gaebler argue that the public sector organizations are substantially restructured by the diffusion of 'entrepreneurial governance', that is by implementing 'private business elements' such as competition, outcomes, redefinition of clients into customers, earning money instead of spending it, market mechanisms instead of bureaucracy, and so on. Birnbaum (2000, p. 3) considers such developments to be "academic management fads" which "follow the cycle of educational innovation in general". Whereas NPM in the US focused on the creation of an "entrepreneurial, empowering government", with an emphasis on accountability and performance indicators, Europe now concentrates on how the "unified and powerful central state apparatus" (Pollitt and Bouckaert 2000, p. 281) has evolved into a more modern governing body.

The influences of NPM are visible as universities and academics are held accountable for the quality of their performance (Deem 1998; Roberts 2001) and consequently have to control and improve the quality of their output (Deem 1998, 2001; Halsey 1995; Pollitt and Bouckaert 2000). Various authors (e.g., Hood 1995; Maassen 2000; Sizer and Cannon 1999; Barry et al. 2001; Parker and Jary 1995) agree on the fact that there is a greater need for measurement of performances specifically in higher education organizations. We define managerialism here as the trend of adopting organizational characteristics, such as organizational forms, technologies, management instruments and values that originate from the private sector organizations (Deem 1998). The timing, pace, and extent of managerialism adoption show some variation among countries (Hood 1995; Pollitt and Bouckaert 2004). In addition, the phenomenon of cultural differences is not limited to the level of countries. Within a country, considerable cultural differences may exist among universities (Shattock 1999), departments (Chan 2001) and even among the perceptions of individual employees (Davies 2007; Ylijoki 2003). The 'within variance' may be considerably larger than the 'between variance'. In other words, individual employees in the same country or institution may perceive different levels of managerialism. This study focuses on the opinion of 
individuals because it is the employees' perceptions of managerialism that possibly affect their performances and attitudes.

NPM should be considered 'a series of overlapping elements consisting of a cluster of ideas borrowed from the conceptual framework of administration in the private sector' (Farrell and Morris 2003, p. 136). Managerialism leads in a similar direction as NPM, but it is more ideologically connoted as it involves the commercialization of public services, including the creation of the quasi-market and the idea that public services could be run analogous to the private sector (Aucoin 1990; Farrell and Morris 2003).

The impact of managerialism (also called private management adaptation) on quality of performances can be considered in at least three different contexts. First, it can be seen in a national or even international context, as part of the broad policy developments, triggered by New Public Management and Public Management Reform. The new division of responsibilities between state and public sectors has involved a change from more directive, process-oriented management based on regulations towards more result-oriented management with emphasis on the quality of performances (Bouckaert and Peters 2002; OECD 1995). The intention of central governments is to appear more accountable to their citizens by making the public sector organizations more responsible for using their financial resources efficiently. Indirectly, governments encourage public sector organizations to report back to their 'consumers' on the results of their activities. This occurred for example in the Dutch vocational education sector (Van Esch 2005).

Second, managerialism can be studied from an organizational context, where we consider the university as a professional organization. Professional steering on the basis of content is through managerial influences gradually being replaced by increased output control. This context has been discussed for example by Czarniavska and Genell (2002), who observe that the standard problem of universities, in comparison with other sites of knowledge production, is being approached with a standard solution: quality assurance, evaluation and ranking, consequently leading to a transformed identity of the universitarian organization.

And third, managerialism can be viewed in an HRM context, emphasizing the relationships between HRM practices and quality of performances, influencing the individual employees within the university as a labor organization. While managerialism increasingly sets the tone in their working context, employees generally stick to values that are in line with university as a meritocratic institution (Acker 1994), that is characterized by financial autonomy, professionalism, collegiality, and intellectual freedom (Barry et al. 2001; Bryson 2004; Chan 2001; Shattock 1999). This research should be perceived within this third context.

As a consequence of the reforms mentioned in the above, a conflict may emerge between the professional employee values, acquired during education and professional socialization and the 'managerial' organization values, embodied in the new conditions of their work (Hackett 1990; Townley 1997). The rather special role of university employees does not easily mix with the new tasks and demands resulting from university reforms (Fruytier and Timmerhuis 1996; Salter and Tapper 2002). This conflict may actually result in a loss of organizational commitment, as previous studies support this expectation by suggesting that university employees demonstrate a poorer work ethos, negative feelings, and resist changes strongly (e.g., Chan 2001; Fave-Bonnet et al. 1999; Fruytier and Timmerhuis 1996; Henkel and Kogan 1996; Potocki-Malicet et al. 1999; Trow 1994b; Välimaa et al. 1998; Ylijoki 2003). It is this conflict which we call the 'managerial contradiction'.

De Boer et al. (2007) explain that there are many similarities across European higher education systems in terms of shifts in governance and policy developments. One of them is the strengthening of the university as a corporate actor. In addition, public sector reforms have resulted in the construction of the university as a 'more complete organization' 
(Enders 2002). Because it is our purpose to investigate universities within the context of public management reform, we have therefore chosen to consider universities (and within them departments) in terms of separate organizational units and identities, and not as e.g., loosely coupled systems (Weick 1976) or as mere umbrella structures where academics like to be left alone (Clark 1983).

This coincides with our approach to commitment. While professional commitment received ample attention (e.g., the overview provided by Ackroyd et al. 2007); research on organizational commitment is still scarce in supply. Employers focus on ensuring that employees use initiatives in the interest of the organizational perceived need to 'affect the thought processes and the decision premises of employees' (Simon 1991, p. 32) through identification with and commitment to the organization. The managerial developments in the current university setting make organizational commitment of professional workers in a university setting a controversial issue, which deserves further scrutinuous research.

\section{Hypotheses}

In this section we derive hypotheses to test two lines of reasoning underlying a potential managerialism contradiction in contemporary European universities. The first hypothesis assumes that managerialism has a direct effect on the quality of performances ('direct effect argumentation'). The second set of hypotheses assumes that managerialism has an indirect effect on the quality of job performances that is mediated by organizational commitment ('indirect effect argumentation').

\section{Direct Effect Argumentation}

This first line of reasoning assumes that the characteristics of managerialism in universities impede university employees to achieve higher quality of job performances. This is what we call the 'direct effect argumentation'. For example, as a result of the managerial accountability aim (Chan 2001), it has become increasingly necessary to report activities and progress. The development and implementation of these and other bureaucratic procedures compelled university employees to spend more time on such so-called 'secondary' activities. They could also have invested their time in doing research, writing articles, or improving teaching programs. In addition, employees adapt their activities to "the simplifying tendencies of the quantification of outputs" (Trow 1994a, p. 41), which may also lead to lower quality performances. To test this direct effect argumentation underlying a potential managerialism contradiction, we formulate the following hypothesis:

Hypothesis 1: Managerialism as perceived by university employees has a negative effect on the quality of their job performances.

\section{Indirect Effect Argumentation}

An alternative line of reasoning underlying a potential managerialism contradiction suggests that organizational commitment acts as a mediator between the perceived level of managerialism and the quality of job performances. This is what we call the indirect effect argumentation'. In this argumentation, rational-economic managerial organization values, including those emphasizing budget transparency, administrative effectiveness, increased 
competition, output measurement, and financial reward (Stiles 2004), collide with professional employee values that generally focus on individual autonomy, collegiality, and professionalism (Bryson 2004). Because organizational commitment is only expected to occur when employee values match organization values (Allen and Meyer 1990; Kanter 1968), the adoption of managerialism may lead to a loss of organizational commitment (see also Bryson 2004; Chan 2001; Trow 1994b). Organizational commitment, in turn, is expected to be important for stimulating high quality performances (Meyer et al. 1989; Mowday et al. 1982; Peters and Waterman 1982; Porter 1985).

Organizational commitment is usually divided into three components or constructs, i.e., affective, normative, and continuance organizational commitment (Meyer and Allen 1997). Each construct is differently affected by the perceived level of managerialism and differently related to the quality of job performance. Firstly, since it is argued that managerial values collide with professional values (Bryson 2004; Chan 2001; Trow 1994b), we expect that an increase of managerialism results in a decrease of affective organizational commitment. After all, affective commitment covers the individual's attachment to social relationships and to the organization, and develops when an individual becomes involved in, recognizes the value-relevance of, and/or derives his or her identity from the organization. The effect of affective commitment on job performances is considered to be positive by most studies (e.g., Ashforth and Saks 1996; Iles et al. 1990; Meyer et al. 1989; Meyer et al. 2002), albeit that some report a weak or statistically insignificant relationship (e.g., Keller 1997).

Secondly, similar to affective commitment, as a result of a value conflict we expect that the level of perceived managerialism negatively affects normative commitment. Because normative commitment concentrates on the internalization of norms and values and on inner convictions, university employees may not be able to internalize the managerial norms and values and consequently fail to develop a feeling of moral obligation to remain with the organization. Furthermore, normative commitment appears to be positively, negatively or not related at all to job performance in different studies (e.g., Allen and Meyer 1996). Most of the studies, however, reveal a positive relationship with performance (e.g., Meyer et al. 2002), although often less strong than the relationship between affective commitment and performance (Marchiori and Henkin 2004; Meyer and Allen 1991).

Finally, as a result of an increased use of performance measurement and performancerelated pay, university employees are more conscious of how their performances are related to costs (e.g., leaving the organization) and rewards (e.g., bonuses). We expect that they consequently become more calculative and increasingly develop stronger continuance commitment. This commitment involves social roles and positions from which individuals derive their perception of the costs associated with leaving the organization and the rewards related to participation in the organization. Furthermore, earlier attempts of empirically tracing the link between continuance organizational commitment and quality of job performances report statistically insignificant relationships (e.g., Hackett et al. 1994; Mayer and Schoorman 1992; Meyer and Allen 1991; Somers and Birnbaum 1998). These results are, however, not always supported by the work of others, who have found clear negative associations (Meyer and Allen 1997; Meyer et al. 1989). They argue that employees with strong continuance commitment behave negatively in reaction to the "no choice' situation (i.e., they have to remain anyhow with the organization) (Meyer and Allen 1997) or perform passively in reaction to the learned helplessness (Seligman 1975) that is promoted by a strong continuance commitment (Meyer and Allen 1997).

In resume, the above indirect effect argumentation assumes that managerialism negatively affects affective and normative commitment and positively affects continuance 


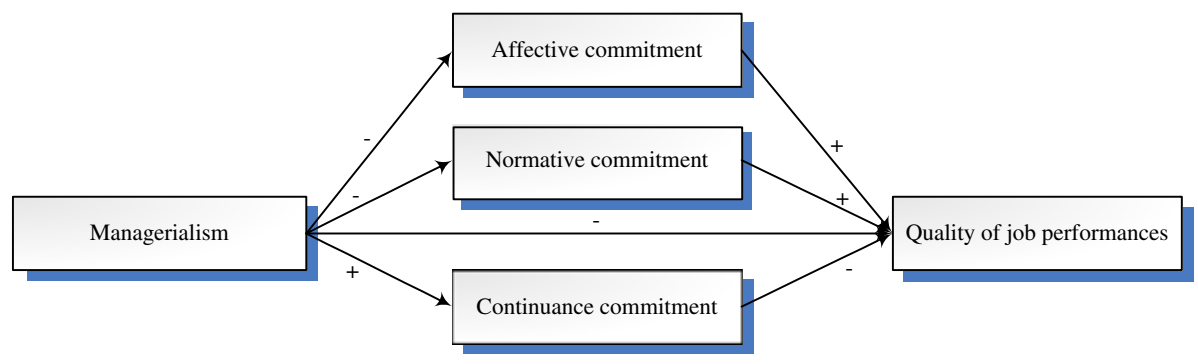

Fig. 1 Hypothesized direct and indirect effects of managerialism on quality of job performances

commitment. These commitment forms, in turn, have either a positive (affective and normative) or a negative (continuance) effect on the quality of job performances. To test the indirect effect argumentation, the following hypotheses are formulated.

Managerialism as perceived by university employees has a negative effect on the quality of their job performances because:

Hypothesis 2a: Managerialism has a negative effect on affective organizational commitment, which in turn has a positive effect on quality of job performances.

Hypothesis 2b: Managerialism has a negative effect on normative organizational commitment, which in turn has a positive effect on quality of job performances.

Hypothesis 2c: Managerialism has a positive effect on continuance organizational commitment, which in turn has a negative effect on quality of job performances.

Accordingly, the postulated direct and indirect effect relationships between managerialism, organizational commitment, and quality of performances are shown in Fig. 1.

As can be seen, the direct effect of managerialism on quality of performances and the indirect effects via the multiple commitment mediators are all assumed to be negative. Hence, altogether managerialism is hypothesized to lead to lower-quality performances.

\section{Methods}

Data and Sample

The study draws on a Web survey conducted from November 2004 to January 2005 among European university employees associated with teaching, research and support. The employees were sampled from 36 departments of 18 universities (two departments per university) equally divided over six European countries (Belgium, Finland, Germany, the Netherlands, Sweden, and the UK). We chose these countries because they are expected to reflect different levels of managerialism adoption (Bleiklie 2001; Hood 1995; Pollitt and Bouckaert 2004), but at the same time are reasonably comparable in socio-economic terms. In addition, knowledge of the English language in these countries is generally sufficient to be able to fill in the questionnaire, designed in English.

Within these countries we selected all universities that have both a business/economics department and a social sciences department or equivalents thereof. We decided to exclude humanities, beta and medical departments in order to maintain our sample relatively homogeneous. We chose two gamma departments per university (business/economics and social sciences) because they are expected to reflect different levels of managerialism 
adoption but are relatively similar otherwise. After all, levels of managerialism do not only differ among countries, but also within countries, within universities and even within departments (Bleiklie 2001; Hood 1995; Pollitt and Bouckaert 2004; Shattock 1999; Y1ijoki 2003). We randomly picked three universities (and consequently six departments) per country and searched for the email addresses of the employees of these selected departments on the Internet.

We conducted the survey across the Internet as all university staff is generally provided with access to the Net. Although Web surveys are relatively new for data collection, several researchers have found support for use of this medium (e.g., Cobanoglu et al. 2001; Sills and Song 2002). After deletion of ineligible respondents, a sample size of 2,325 European university employees was obtained, implying a response of $28.9 \%$. The sample proportions with respect to sex, age, and employment were similar to the population proportions. In other words, the sample did not differ significantly from the population with respect to these characteristics (Smeenk et al. 2006).

\section{Questionnaire}

The questionnaire was structured to encourage the respondents to reflect on their past and present experiences in the department. Following Swoboda et al. (1997) we tried to keep the questionnaire as short and simple as possible. The question about the number of academic activities (articles, books, presentations, etc.) the respondent had performed since January 1 2002, was not relevant for support and administrative employees and for student assistants. The position in the department was used as a filter. All other questions were formulated in a way to be relevant to all respondents. The questionnaire was pre-tested in the summer of 2004 by a pilot survey held in two Dutch departments (a business/economics department and a social sciences department) of the same university (Smeenk et al. 2008). The results of this pilot study led to some minor adaptations of the formulation and sequence of the questions.

\section{Measurements}

Standard and study-specific measures are provided for the perceived level of managerialism, the three organizational commitment constructs, and the quality of job performances.

\section{Perceived Level of Managerialism}

The managerial developments involve seven dimensions: extent of segregation (expansion of student numbers and diversification of study disciplines), competition between universities or departments, use of management practices drawn from the private sector, stress on discipline and parsimony in resource use, move towards more hands-on management, move towards more explicit and measurable standards of performance, and attempts to control according to pre-set output measures (Hood 1995). University employees were asked to indicate to what extent they perceive these dimensions apply to their department $(1=$ does not apply at all, $5=$ applies completely $)$.

\section{Organisational Commitment}

Organizational commitment can be measured by a number of different scales (e.g., Penley and Gould 1988; Porter et al. 1974). Based on Mowday et al. (1979); Buchanan (1974), and Quinn and Staines (1979), Allen and Meyer (1990) developed the 24-item 
Organizational Commitment Questionnaire (OCQ), which has become a widely used instrument to measure affective, normative, and continuance organizational commitment (e.g., Buck and Watson 2002; Gaertner and Nollen 1989). We also used the OCQ, which consists of three subscales: the Affective Commitment Scale (ACS), the Normative Commitment Scale (NCS), and the Continuance Commitment Scale (CCS). We tried to improve the scale items by reducing item ambiguity and deleting equivalent and irrelevant items, and used six items for each subscale. Responses were made on a five-point continuum $(1=$ totally disagree, $5=$ totally agree $)$.

\section{Quality of Job Performances}

Data on the quality of job performances have been acquired using two measures. Firstly, we asked the respondents how they think their colleagues would rate the quality of the respondents overall performances and, if applicable, the quality of their research, their teaching, and their management performances (ranging from bottom 10\% to highest $10 \%$ ). Secondly, the actual performances of the academics have been measured by asking them to indicate how many articles they have published in refereed and non-refereed journals, how many chapters in edited volumes they have published, how many textbooks or other books they have disseminated, the number of research reports they have disseminated internally or to external clients, and the number of presentations they have held at conferences and workshops in the past 3 years. The ratings on these items have been summed to generate a single composite score.

\section{Common Method Variance}

To control for the potential effects of common method variance (Podsakoff et al. 2003), we applied different response formats for the measurement of the perceived level of managerialism (five-point Likert scale with 'don't know'-option), organizational commitment (five-point Likert scale), and the quality of job performances (five-point scale with 'not applicable' - option and numerical entry). Moreover, on the basis of qualitative research on the formulation of the items and the pilot study, we improved scale items by reducing item ambiguity, social desirability, and demand characteristics, and we deleted equivalent and irrelevant items. Since we applied tested and widely used scales to measure most of the concepts, we were careful in altering the scale formats and scale values in order to preserve the original scale validities.

We conducted the Harman's one-factor test (Harman 1967) as described by Podsakoff et al. (2003) to test for common method bias. As the unrotated principal component factor analysis of all relevant variables resulted in 12 components, with the first component only accounting for $13.9 \%$ of the variance, our findings are not much affected by the problem of common method variance.

\section{Factor Analysis}

For the purpose of data reduction, we conducted factor analysis using principal-axis extraction. On the basis of previous research (Smeenk et al. 2008; Meyer and Allen 1997), we expected a six-factor solution: two factors representing the perceived level of managerialism, three factors representing organizational commitment, and one factor representing the quality of job performances. In addition, we deleted items with communalities less than .20 and items with equivalent loadings (of at least .25) on two or more factors. 
Table 1 Factor analysis

$\mathrm{h}^{2} \quad$ Pattern matrix ${ }^{\mathrm{a}}$

\begin{tabular}{llllll}
\hline I & II & III & IV & V & VI
\end{tabular}

Private management adoption $\left(\alpha=.54 / \alpha=.73^{\mathrm{b}}\right)$

Explicit measuring standards are the largest part of the quality evaluation in the faculty

In the faculty, the evaluation of teaching and research is mainly carried out with assessment criteria set by 'the managers' rather than by 'peers'

The faculty has increasingly applied private sector management techniques, such as performance management and efficiency controlling

The faculty is under pressure to compete with similar faculties at other universities ${ }^{\mathrm{c}}$

The faculty is under pressure to reduce expenditures

The faculty's management is characterised by a control orientation rather than a developmental orientation

Faculty segregation $\left(\alpha=.44 / \alpha=.70^{\mathrm{b}}\right)$

The number of study disciplines in the faculty has increased since I started working here

The number of student enrolments to the faculty has increased since I started working here

Affective organizational commitment $\left(\alpha=.83 / \alpha=.85^{\mathrm{b}}\right)$

I would be very happy to spend the rest of my career at the .42 faculty

I enjoy discussing the faculty in a positive sense with people $\quad .57$ outside it

I really feel as if the faculty's problems are my own $\quad .46$

I feel like 'part of the family' at the faculty

$.67 \quad .80$

The faculty has a great deal of personal meaning for me

$.69 \quad .81$

I easily become as attached to another organization as I am to this one $(R)^{\mathrm{d}}$

Normative organizational commitment $\left(\alpha=.64 / \alpha=.73^{\mathrm{b}}\right)$

Employees generally move from organization to organization too often

I do not mind at all when employees jump from organization to organization (R)

I believe in the value of remaining loyal to one organization $\quad .39$

I think that wanting to be a 'company man or woman' is still .22 sensible

If I got offered a job elsewhere I would feel uncomfortable to leave the faculty

Nowadays, things are better than in the days when people stayed with one organization for most of their careers $(R)$

Continuance organizational commitment $\left(\alpha=.77 / \alpha=.77^{\mathrm{b}}\right)$

I am afraid of what might happen if I quit my job without .31 having another one lined up

It would be very hard for me to leave the faculty right now $\quad .54$ 
Table 1 continued

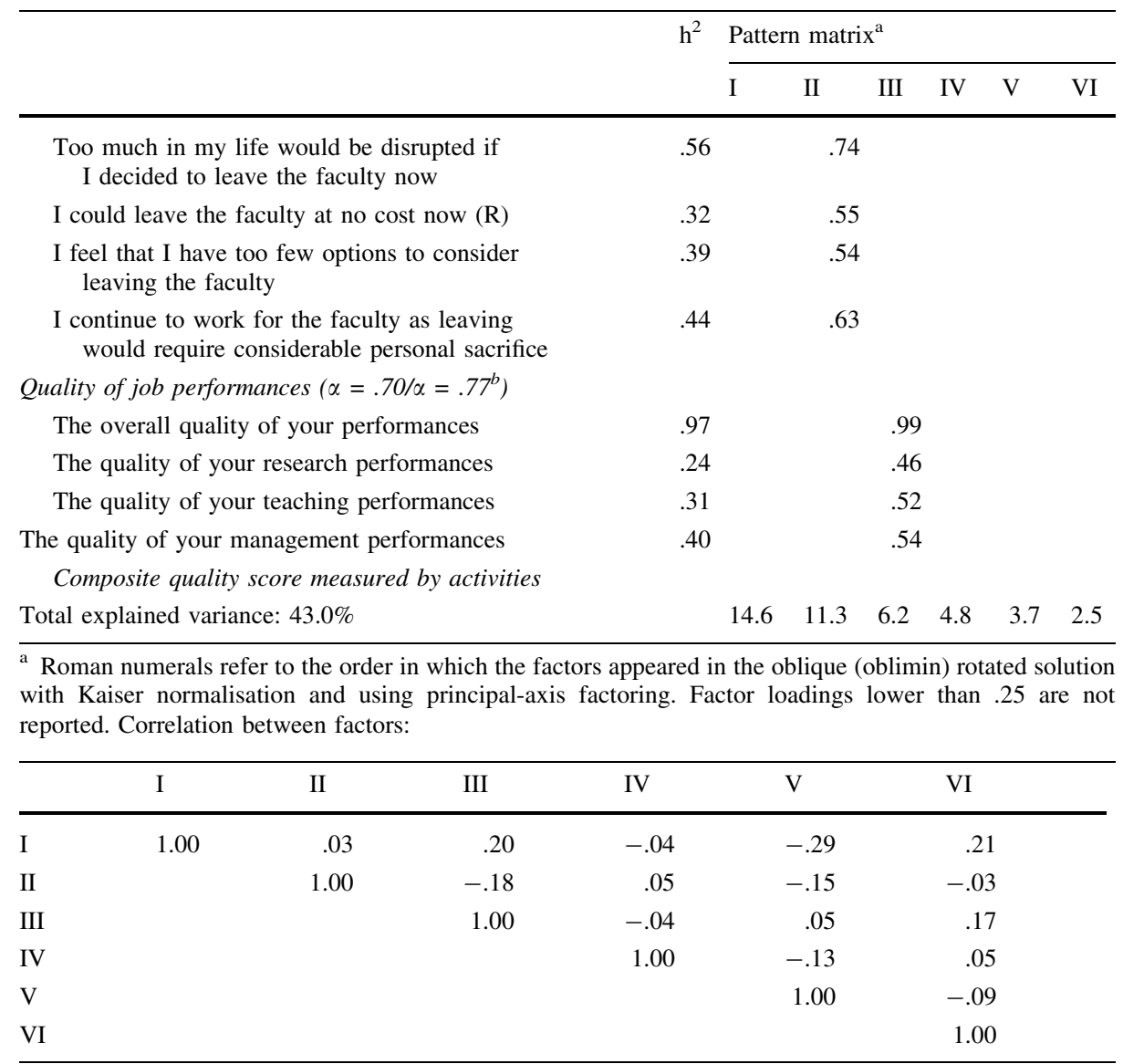

${ }^{\mathrm{b}}$ We calculated the six-item reliability using the Spearman-Brown formula: $\mathrm{r}_{\mathrm{kk}}=\mathrm{k} * \mathrm{r}_{\mathrm{xx}} / 1+\left([\mathrm{k}-1] * \mathrm{r}_{\mathrm{xx}}\right)$, where $r_{k k}$ is the reliability of the scale that has $\mathrm{k}$ times as much items as the original scale, $r_{\mathrm{xx}}$ is the reliability of the original scale, and $\mathrm{k}$ is the multiplier

c Items in italics were excluded from the analysis because of low communality $(<.20)$

d Reversed items are indicated with (R)

Table 1 summarizes the results of the oblimin-rotated factor analysis of the variables used in our study.

The data in Table 1 reveal that the perceived level of managerialism consists of two uncorrelated factors. Looking at the items that belong to each factor, we see that one factor is related to the adoption of private management and that the other is related to the segregation of university departments. Therefore, we labeled these factors private management adoption and department segregation, respectively. Further, organizational commitment consists of three factors-affective, normative, and continuance commitmentthat are intercorrelated up to .29. These results support Allen and Meyer's findings (1990) that affective, normative and continuous commitment are both conceptually and empirically separable components of organizational commitment. Finally, the 'quality of job performances' items appear to constitute a single factor. 


\section{Results}

To test the direct and indirect effects hypotheses formulated in the Sect. "Hypotheses", we used the multiple mediator model as discussed by Preacher and Hayes (2006). All estimates presented below were controlled for country and department type, and for three personal variables - age, gender, and organizational tenure-that were shown to be important for university employees' organizational commitment in a previous study (Smeenk et al. 2008). Further, the variance inflation factor (VIF) values in all analyses ranged from 1.00 to 2.17, which is much lower than the recommended cut-off threshold of 10 (Hair et al. 1998). This indicates that there is no problem of multicollinearity. The unstandardized regression coefficients along with their standard errors (in parentheses) are presented in Table 2.

The results in Table 2 are used to test the hypotheses concerning the direct and indirect lines of reasoning underlying a potential managerialism contradiction. According to the direct effect argumentation, managerialism as perceived by university employees has a negative effect on the quality of their job performances. The findings indicate that the private management part of managerialism has no significant direct effect on the quality of

Table 2 Unstandardised direct, indirect and total effects from multiple mediator model estimating the effect of managerialism on quality of job performances with affective, normative, and continuance organizational commitment as mediators (standard error in parentheses)

\begin{tabular}{|c|c|c|c|}
\hline \multirow[b]{2}{*}{ Direct effect } & \multicolumn{3}{|c|}{ Quality of job performances } \\
\hline & & & \\
\hline Managerialism: Private management adoption & & $-.011(.033)$ & \\
\hline Faculty segregation & & $.118(.037)^{*}$ & \\
\hline Affective commitment (AC) & & $.224(.025)^{*}$ & \\
\hline Normative commitment (NC) & & $-.047(.029)$ & \\
\hline Continuance commitment (CC) & & $-.123(.025)^{*}$ & \\
\hline Direct effect on mediator & $A C$ & $N C$ & $C C$ \\
\hline Managerialism: Private management adoption & $.007(.032)$ & $.080(.028)^{*}$ & $.076(.031)^{*}$ \\
\hline Faculty desegregation & $.128(.035)^{*}$ & $.089(.031)^{*}$ & $-.011(.035)$ \\
\hline Indirect effect via mediator & $A C$ & $N C$ & $C C$ \\
\hline Managerialism: Private management adoption & $.002(.008)$ & $-.004(.003)$ & $-009(.005)^{*}$ \\
\hline Faculty segregation & $.029(.009)^{*}$ & $-.004(.003)$ & $.001(.005)$ \\
\hline \multicolumn{4}{|l|}{ Total indirect effect } \\
\hline Managerialism: Private management adoption & & $-.012(.009)$ & \\
\hline Faculty segregation & & $.026(.010)^{*}$ & \\
\hline \multicolumn{4}{|l|}{ Total effect } \\
\hline Managerialism: Private management adoption & & $-.022(.034)$ & \\
\hline Faculty segregation & & $.144(.038)^{*}$ & \\
\hline Adjusted $\mathrm{R}^{2}$ & & .062 & \\
\hline
\end{tabular}

* Coefficient is greater than two times the standard error. The program INDIRECT by Preacher and Hayes (2006) was used to assess the significance of the indirect effects. The standard errors of the indirect effects are obtained by bootstrapping using 5.000 bootstrap samples. The standard errors for the other effects are obtained by OLS. The parameters estimates are controlled for country, faculty type, age, gender, and organizational tenure 
performances $(\mathrm{b}=-.011, P=.747)$ and that the direct effect of the department segregation factor is positive $(\mathrm{b}=.118, P=.002)$. Both results clearly refute Hypothesis 1 .

The indirect effect argumentation maintains that the negative effect of managerialism on the quality of job performances is indirect and mediated by organizational commitment. Firstly, when we look at the influence of managerialism on affective commitment, we see that the effect of private management adoption is not significant $(\mathrm{b}=.007, P=.836)$ and that the effect of department segregation is positive $(b=.128, P=.000)$. When employees have higher levels of affective commitment, they deliver job performances of higher quality $(\mathrm{b}=.224, P=.000)$. However, the indirect effect of private management adoption on quality of performances via affective commitment is statistically insignificant $(\mathrm{b}=.002$, se $=.008)$ and the indirect effect of department segregation via affective commitment is positive $(\mathrm{b}=.029$, se $=.009)$. Hence, these findings do not support Hypothesis 2a.

Secondly, university employees feel more moral obligation to stay with the department (normative commitment) when they experience higher levels of private management adoption $(\mathrm{b}=.080, P=.004)$ and department segregation $(\mathrm{b}=.089, P=.004)$. Normative commitment, in turn, has however no significant effect on quality of performances ( $\mathrm{b}=-.047, P=.109$ ). As a result, the indirect effects of both private management adoption and department segregation on the quality of job performances via normative commitment are not significant (for both: $b=-.004$, se $=.003$ ). These results fail to corroborate Hypothesis $2 b$.

Thirdly, continuance commitment increases $(b=.076, P=.016)$ when employees increasingly perceive use of performance management, efficiency controlling, and evaluation with explicit measuring standards set by 'the managers' (private management adoption). Department segregation has no significant effect on the level of continuance commitment ( $\mathrm{b}=-.011, P=.746)$. Employees' continuance commitment, in turn, is negatively related to quality of performances $(\mathrm{b}=-.123, P=.000)$. Moreover, while the indirect effect of department segregation on the quality of job performances via continuance commitment is not significant $(b=.001$, se $=.005)$, the indirect effect of private management adoption is negative $(\mathrm{b}=-.009$, se $=.005)$. Hence, the findings corroborate Hypothesis 2c, but only as far as the private management aspect of managerialism is concerned.

Finally, when we look at the total indirect effects of the organizational commitment constructs, we see that that private management adoption has no significant total indirect effect on the quality of job performances $(b=-.012$, se $=.009)$, whereas the total indirect effect of department segregation is positive $(b=.026$, se $=.010)$. The total (direct and indirect) effects of the managerialism factors indicate that private management adoption has no effect on the quality of job performances and that the overall effect of department segregation is positive $(\mathrm{b}=.144, P=.000)$.

\section{Discussion and Conclusion}

In this paper, two lines of reasoning (the direct and the indirect effect argumentation) that possibly explain a managerialism contradiction in contemporary European universities have been tested empirically. The results of our study indicate that the private management factor of managerialism has no direct effect on the quality of job performances. There is a weak negative indirect effect via continuance commitment, but this effect is cancelled out by other indirect effects resulting in a statistically insignificant total indirect effect. With 
regard to the department segregation factor of managerialism, it appears that this factor has a positive direct effect on the quality of performances. Also, department segregation additionally affects job performances indirectly via organizational commitment in general and affective commitment in particular. Evidence for a managerialism contradiction is thus largely absent among European university employees. Such contradiction is, if at all present, constrained to a small negative effect of managerialism on performance via continuance organizational commitment. By and large, managerialism does not work against its own intentions. To the contrary, as evidenced by the effect of department segregation, it is more likely to foster quality of job performances. As our investigations are limited to six European countries, it is not possible to generalize our findings to the American Higher Education system. Although similar features of managerialism occur today in the US, such as performance-based accountability, reforms in state governance of higher education, and privatization, we cannot tell whether a managerialism contradiction exists in the US and which possible effects such a contradiction might have on the performance of the university faculty. Since the influence of political bodies in the US has always been much more limited, the impact of a managerialism contradiction seems unlikely. However, a cross-Atlantic comparison concerning the impact of managerialism in higher education should certainly fill this gap.

In addition to the effects examined above, it could be that managerialism itself affects the influence of organizational commitment on quality of job performances. In other words, university employees could be as committed as they were under a managerial regime but the effect of this commitment has changed as a result of increased managerialism. We were not able to find studies that make notice of this moderating relationship. Moreover, when we tested this possibility, the results indicated that there is no moderating effect of managerialism on the relationship between organizational commitment and quality of job performances at all. We therefore did not include this line of reasoning as a possible argumentation underlying a managerialism contradiction.

We can think of three perspectives that may provide an explanation for the results that point to the absence of a managerialism contradiction. The first perspective is that there is no conflict at all. It may be that professional employee values can co-exist with managerial values. This idea is supported by research of others. For example, Becher and Kogan (1992) argue that "management values in higher education are not intrinsically hostile to professional values" (p. 179). Gewirtz et al. (1995) suggest that professional values have not entirely disappeared but that some employees switch between two sets of values according to the context, although accepting the new emphasis on markets and competition is often difficult for them.

The second perspective suggests that universities retain their character by adapting the managerialism ideology and values (see also Deem and Brehony 2005). In terms of Translation Theory, which is based on Callon/Latour's Actor-network Theory, a 'translation' takes place: "all actors discuss, interpret, modify, and alter the core ideas of the new management fashion" (Doorewaard and Van Bijsterveld 2001, p. 60; see also Callon 1986; Latour 1986). Prichard and Willmott (1997) support this idea by suggesting that "localized practices and existing discursive regimes have a strong mediating effect on the reception and articulation of 'management disciplines' (p. 311). Christensen and Lægreid (1999) argue that managerial features are filtered, interpreted and adjusted in accordance with national and institutional cultures, traditions and contexts.

The third perspective assumes that universities, which tend to be deeply conservative when it comes to organizational change (Dearlove 1998), are in a period of transition. A possible conflict between professional and managerial may merely be the expression of 
transitional problems (e.g., De Boer et al. 1998), which will slowly fade away over the years. This idea is supported by the suggestion of Gibbons et al. (1994) that universities are moving from one stage of academic governance to another.

A practical implication that results from our findings is that practitioners in the field of university HRM should try to affect organizational commitment in order to increase university employees' quality of job performances. After all, our study demonstrates that if a managerialism contradiction exists, particularly continuance organizational commitment mediates the relationship between managerialism and the quality of job performances.

We are aware that our research has some limitations that must be considered in evaluating the study's findings. A first limitation concerns the instrument and method used for collecting the commitment data. The instrument is an attitudinal survey and therefore based on the individual respondent's emotional state at the time. Although we have taken organizational factors into account, our results are based on the perceptions held by the individual respondents. We were unable to control for organizational and institutional characteristics that may influence the effect of managerialism on the quality of job performance, such as size, research mission, market segmentation or institutional prestige. Secondly, as the complex nature of quality of performances cannot be captured in its totality by personal impressions and counting publications, we are thoroughly conscious that this study only gives a quantitative insight into the relationships between managerialism, organizational commitment, and quality of job performances. Finally, we did not account for the differences between the cultures of the sample countries. Further research may address these differences by analyzing whether the levels of organizational commitment and quality of performances are significantly different between particular countries. Since organizational commitment appears to be an important factor in contemporary universities, future research could also focus on the factors that affect university employees' organizational commitment and the comparison of these relationships among institutions with different levels of (perceived) managerialism.

Open Access This article is distributed under the terms of the Creative Commons Attribution Noncommercial License which permits any noncommercial use, distribution, and reproduction in any medium, provided the original author(s) and source are credited.

\section{References}

Acker, S. (1994). Gendered education: Sociological reflections on women, teaching and feminism. Buckingham, England: Open University Press.

Ackroyd, S., Kirkpatrick, I., \& Walker, R. (2007). Public management reform and its consequences for professional organisation: A comparative analysis. Public Administration, 1, 28-47.

Allen, N. J., \& Meyer, J. P. (1990). The measurement and antecedents of affective, continuance and normative commitment to the organization. Journal of Occupational Psychology, 63, 1-18.

Allen, N. J., \& Meyer, J. P. (1996). Affective, continuance and normative commitment in the organization: An examination of construct validity. Journal of Vocational Behavior, 49, 252-276.

Ashforth, B. E., \& Saks, A. M. (1996). Socialization tactics: Longitudinal effects on newcomer adjustment. Academy of Management Journal, 39, 149-178.

Aucoin, P. (1990). Administrative reform in public management: Paradigms, principles, paradoxes and pendulums. Governance: An International Journal of Policy and Administration, 2, 115-137.

Barry, J., Chandler, J., \& Clark, H. (2001). Between the ivory tower and the academic assembly line. Journal of Management Studies, 38, 87-101.

Becher, T., \& Kogan, M. (1992). Process and structure in higher education. London: Routledge.

Birnbaum, R. (2000). The life cycle of academic management fads. The Journal of Higher Education, 71(1), $1-16$. 
Bleiklie, I. (2001). Towards European convergence of higher education policy? Higher Education Management, 13(3), 9-29.

Bouckaert, G., \& Peters, B. G. (2002). Performance measurement and management: The Achilles' heel in administrative modernization. Public Performance and Management Review, 25(4), 359-362.

Boyne, G. A. (2002). Public and private management: What's the difference? Journal of Management Studies, 39(1), 97-122.

Bryson, C. (2004). The consequences for women in the academic profession of the widespread use of fixed term contracts. Gender, Work and Organization, 11, 187-206.

Buchanan, B. (1974). Building organizational commitment: The socialization of managers in work organizations. Administrative Science Quarterly, 19, 533-546.

Buck, J. M., \& Watson, J. L. (2002). Retaining staff employees: The relationship between human resources management strategies and organizational commitment. Innovative Higher Education, 26, 175-193.

Callon, M. (1986). Some elements of a sociology of translation: Domestication of the scallops and the fishermen of Saint Brieuc Bay. In J. Law (Ed.), Power, action and belief (pp. 196-233). London: Routledge and Kegan Paul.

Chan, K. (2001). The difficulties and conflict of constructing a model for teacher evaluation in higher education. Higher Education Management, 13(1), 93-111.

Christensen, T., \& Lægreid, P. (1999). New public management—design, resistance, or transformation? A study of how modern reforms are received in a civil service system. Public Productivity and Management Review, 23, 169-193.

Clark, B. R. (1983). The higher education system. Berkeley: University of California Press.

Clark, B. R. (1998). Creating entrepreneurial universities: Organizational pathways of transformation. Great Britain: Pergamon.

Clarke, J., \& Newman, J. (1997). The managerial state: Power, politics and ideology in the remaking of social welfare. London: Sage.

Cobanoglu, C., Warde, B., \& Moreo, P. J. (2001). A comparison of mail, fax and web-based survey methods. International Journal of Market Research, 43, 441-452.

Cozzens, S., Healey, P., Rip, A., \& Ziman, J. (Eds.). (1990). The research system in transition. Boston: Kluwer Academic Publishers.

Czarniavska, B., \& Genell, K. (2002). Gone shopping? Universities on their way to the market. Scandinavian Journal of Management, 18(4), 455-474.

Davies, C. (2007). Grounding governance in dialogue? Discourse, practice and the potential for a new public sector organizational form in Britain. Public Administration, 85(1), 47-66.

Davies, A., \& Thomas, R. (2002). Managerialism and accountability in higher education: The gendered nature of restructuring and the costs to academic service. Critical Perspectives on Accounting, 13, 179-193.

de Boer, H. F., Enders, J., \& Leisyte, L. (2007). Public sector reform in Dutch higher education: The organizational transformation of the university. Public Administration, 85(1), 27-46.

de Boer, H., Goedegebuure, L. C. J., \& Meek, L. (1998). Editorial: 'In the winter of discontent, business-as usual'. Higher Education Policy, 11, 103-110.

Dearlove, J. (1998). Fundamental changes in institutional governance structures: The United Kingdom. Higher Education Policy, 11, 111-120.

Deem, R. (1998). 'New managerialism' and higher education: The management of performances and cultures in universities in the United Kingdom. International Studies in Sociology of Education, 8, 47-70.

Deem, R. (2001). Globalisation, new managerialism, academic capitalism and entrepreneurialism in universities: Is the local dimension still important? Comparative Education, 37(1), 7-20.

Deem, R., \& Brehony, K. J. (2005). Management as ideology: The case of 'new managerialism' in higher education. Oxford Review of Education, 31, 217-235.

Dent, M. (2005). Post-new public management in public sector hospitals: The UK, Germany and Italy. Policy and Politics, 33(4), 623-636.

Dent, M., van Gestel, N., \& Teelken, C. (2007). Changing modes of governance in public sector organizations: Action and rhetoric. Public Administration, 1, 1-8.

Doorewaard, H., \& van Bijsterveld, M. (2001). The osmosis of ideas: An analysis of the integrated approach to IT management from a Translation Theory perspective. Organization, 8, 55-76.

Enders, J. (2002). Governing the academic commons: About blurring boundaries, blistering organisations, and growing demands, the CHEPS Inaugurals. Enschede: CHEPS.

Etzkowitz, H., \& Leydesdorff, L. (2000). The dynamics of innovation: From national systems and 'Mode 2' to a Triple Helix helix of university-industry-government relations. Introduction to the special Triple Helix issue. Research Policy, 29(2), 109-123. 
Farrell, C., \& Morris, J. (2003). The 'Neo-Bureaucratic' state: Professionals, managers and professional managers in schools, general practices and social work. Organization, 10(1), 129-156.

Fave-Bonnet, M., Estrela, M., Veiga-Simao, A., \& Moscati, R. (1999). The evaluation of teacherresearchers. European Journal of Education, 34, 313-323.

Fruytier, B. G. M., \& Timmerhuis, V. C. M. (1996). Mensen in onderzoek: Het mobiliseren van human resources in wetenschapsorganisaties. Management and Organisatie, 50, 424-448.

Gaertner, K. N., \& Nollen, S. D. (1989). Career experiences, perceptions of employment practices, and psychological commitment to the organization. Human Relations, 42, 975-991.

Gewirtz, S., Ball, S., \& Bowe, R. (1995). Markets, choice and equity in education. Buckingham: Open University Press.

Gibbons, M., Limoges, C., Nowotny, H., Schwartzmann, C., Scott, P., \& Trow, M. (1994). The new production of knowledge: The dynamics of science and research in contemporary society. London: Sage Publications.

Hackett, E. J. (1990). Science as a vocation in the 1990s: The changing organizational culture of academic science. Journal of Higher Education, 61, 241-279.

Hackett, R. D., Bycio, P., \& Hausdorf, P. (1994). Further assessment of Meyer \& Allen's 1991 threecomponent model of organizational commitment. Journal of Applied Psychology, 79, 15-23.

Hair, J. E., Anderson, R. E., Tatham, R. L., \& Black, W. C. (1998). Multivariate data analysis (5th ed.). London: Prentice-Hall.

Halsey, A. H. (1995). The decline of donnish dominion. Oxford: Clarendon Press.

Harman, H. (1967). Modern factor analysis. Chicago, IL: University of Chicago Press.

Henkel, M., \& Kogan, M. (1996). The impact of policy changes on the academic profession. Cardiff: University of Wales Institute.

Hood, C. (1991). A public management for all seasons? Public Administration, 69, 3-19.

Hood, C. (1995). The 'New Public Management' in the 1980s: Variations on a theme. Accounting, Organizations and Society, 20, 93-109.

Hood, C., James, O., \& Scott, C. (2000). Regulation of government: Has it increased, is it increasing, should it be diminished? Public Administration, 78(2), 283-304.

Hood, C., Scott, C., James, O., Jones, G., \& Travers, T. (1999). Regulation inside government: Wastewatchers, quality-police and sleaze-busters. Oxford: Oxford University Press.

Iles, P., Mabey, C., \& Robertson, I. (1990). HRM practices and employee commitment: Possibilities, pitfalls and paradoxes. British Journal of Management, 1, 147-157.

Kanter, R. M. (1968). Commitment and social organization: A study of commitment mechanisms in utopian communities. American Sociological Review, 33, 499-517.

Keller, R. T. (1997). Job involvement and organizational commitment as longitudinal predictors of job performance: A study of scientists and engineers. Journal of Applied Psychology, 82, 539-545.

Latour, B. (1986). The powers of association. In J. Law (Ed.), Power, action and belief (pp. 264-280). London: Routledge and Kegan Paul.

Lazzeretti, L., \& Tavoletti, E. (2006). Governance shifts in higher education: A cross-national comparison. European Educational Research Journal, 5(1), 18-37.

Lundvall, B. A. (Ed.). (1992). National systems of innovation. London: Pinter.

Maassen, A. M. (2000). The changing role of stakeholders in Dutch University Governance. European Journal of Education, 35(4), 449-464.

Marchiori, D. M., \& Henkin, A. B. (2004). Organizational commitment of a health profession faculty: Dimensions, correlates and conditions. Medical Teacher, 26, 353-358.

Mayer, R. C., \& Schoorman, F. D. (1992). Predicting participation and production outcomes through a twodimensional model of organizational commitment. Academy of Management Journal, 35, 671-684.

Meyer, J. P., \& Allen, N. J. (1991). A three-component conceptualization of organizational commitment. Human Resource Management Review, 1(1), 61-89.

Meyer, J. P., \& Allen, N. J. (1997). Commitment in the workplace: Theory, research, and application. Thousand Oaks/London: Sage Publications.

Meyer, J. P., Paunonen, S. V., Gellatly, I. R., Goffin, R. D., \& Jackson, D. N. (1989). Organizational commitment and job performance: It's the nature of the commitment that counts. Journal of Applied Psychology, 74, 152-156.

Meyer, J. P., Stanley, D. J., Herscovitch, L., \& Topolnytsky, L. (2002). Affective, continuance, and normative commitment to the organization: A meta-analysis of antecedents, correlates, and consequences. Journal of Vocational Behavior, 61, 20-52.

Mowday, R. T., Porter, L. W., \& Steers, R. M. (1982). Employee-organization linkages: The Psychology of commitment, absenteeism and turnover. New York, NJ: Academic Press. 
Mowday, R. T., Steers, R. M., \& Porter, L. W. (1979). The measurement of organizational commitment. Journal of Vocational Behavior, 14, 224-247.

Neave, G. (2002). The stakeholder perspective historically explored, in J.Enders \& F. Oliver, Higher Education in a Globalizing World: international trends and mutual observations. Dordrecht: Kluwer.

Nelson, R. R. (Ed.). (1993). National innovation systems: A comparative study. New York: Oxford University Press.

OECD. (1995). Governance in transition: Public management reforms in OECD Countries. Paris: PUMA/ OECD.

Osborne, D., \& Gaebler, T. (1992). Reinventing government: How entrepreneurial spirit is transforming the public sector. New York: Basic Books.

Parker, M., \& Jary, D. (1995). The McUniversity: Organization, management and academic subjectivity. Organization, 2, 319-338.

Penley, L. E., \& Gould, S. (1988). Etzioni's model of organizational involvement: A perspective for understanding commitment to organizations. Journal of Organizational Behavior, 9, 43-59.

Peters, T. J., \& Waterman, R. H. (1982). In search of excellence. Lessons from America's best-run companies. New York, NY: Harper and Row.

Podsakoff, P. M., MacKenzie, S. B., Lee, J.-Y., \& Podsakoff, N. P. (2003). Common method biases in behavioral research: A critical review of the literature and recommended remedies. Journal of Applied Psychology, 88, 879-903.

Pollitt, C. (1993). Managerialism and the public services: Cuts or cultural change in the 1990s?. Oxford: Blackwell.

Pollitt, C., \& Bouckaert, G. (2000). Public management reform. A comparative analysis. Oxford: Oxford University Press.

Pollitt, C., \& Bouckaert, G. (2004). Public management reform: A comparative analysis. Oxford: Oxford University Press.

Porter, M. E. (1985). Competitive advantage. New York, NY: Free Press.

Porter, L. W., Steers, R. M., Mowday, R. T., \& Boulian, P. V. (1974). Organizational commitment, job satisfaction and turnover among psychiatric technicians'. Journal of Applied Psychology, 59, 603-609.

Potocki-Malicet, D., Holmesland, I., Estrela, M., \& Veiga-Simao, A. (1999). The evaluation of teaching and learning. European Journal of Education, 34, 299-312.

Preacher, K. J. \& Hayes, A. F. (2006). Asymptotic and resampling strategies for assessing and comparing indirect effects in simple and multiple mediator models. Chapel Hill: University of North Carolina. Available at http://www.comm.ohio-state.edu/ahayes/indirect2.pdf (May 2006).

Prichard, C., \& Willmott, H. (1997). Just how managed is the McUniversity? Organization Studies, 18, 287-316.

Quinn, R. P., \& Staines, G. L. (1979). The 1977 quality of employment survey. Ann Arbor, MI: Institute for Social Research.

RAE (Research Assessment Exercise). (2001). The Outcome. Available at http://www.hero.ac.uk Accessed May 2006.

Rip, A., \& van der Meulen, B. (1996). The post-modern research system. Science and Public Policy, 23(6), $343-352$.

Roberts, V. (2001). Global trends in tertiary education quality assurance. Implications for the anglophone caribbean. Educational Management and Administration, 29(2), 425-440.

Saint Martin, D. (2005). Management consultancy. In E. Ferlie, L. E. Lynn Jr., \& C. Pollitt (Eds.), The Oxford Handbook of Public Management (pp. 671-694). Oxford University Press.

Salter, B., \& Tapper, T. (2002). The external pressures on the internal governance of universities. Higher Education Quarterly, 56, 245-256.

Seligman, M. E. P. (1975). Helplessness: On depression, development, and death. New York: Freeman.

Shattock, M. (1999). Governance and management in universities: The way we live now. Journal of Education Policy, 14, 271-282.

Sills, S. J., \& Song, C. (2002). Innovations in survey research: An application of web-based surveys. Social Science Computer Review, 20, 22-30.

Simon, H. (1991). Organizations and markets. Journal of Economic Perspectives, 5(2), $25-44$.

Sizer, J., \& Cannon, S. (1999). Autonomy, governance and accountability. In J. Brennan, J. Fedrowitz, M. Huber, \& T. Shah (Eds.), What kind of university? International perspectives on knowledge, participation and governance (pp. 37-51). Heerlen: The Society for Research into Higher Education \& Open University Press.

Smeenk, S. G. A., Eisinga, R. N., Teelken, J. C., \& Doorewaard, J. A. C. M. (2006). The effects of HRM practices and antecentents on organizational commitment among university employees. International Journal of Human Resource Management, 17(12), 2035-2054. 
Smeenk, S., Teelken, C., Eisinga, R., \& Doorewaard, H. (2008). An international comparison of the effects of HRM practices and organizational commitment on quality of job performances among European university employees. Higher Education Policy, 21(3), 323-344.

Somers, M. J., \& Birnbaum, D. (1998). Work-related commitment and job performance: It's also the nature of the performance that counts. Journal of Organizational Behavior, 19, 621-634.

Stiles, D. (2004). Narcissus revisited: The values of management academics and their role in business school strategies in the UK and Canada. British Journal of Management, 15, 157-175.

Swoboda, W. J., Mühlberger, N., Weikunat, R., \& Schneeweiss, S. (1997). Internet surveys by direct mailing: An innovative way of collecting data. Social Science Computer Review, 15, 242-255.

Thornhill, A., Lewis, P., \& Saunders, M. N. K. (1996). The role of employee communication in achieving commitment and quality in higher education. Quality Assurance in Education, 4, 12-20.

Townley, B. (1997). The institutional logic of performance appraisal. Organization Studies, 18(2), 261-285.

Trow, M. (1994a). Managerialism and the academic profession: Quality and control. London: Quality Support Centre.

Trow, M. (1994b). Managerialism and the academic profession: The case of England. Higher Education Policy, 7, 11-18.

Välimaa, J., Aittola, T., \& Konttinen, R. (1998). Impacts of quality assessment: The case of Jyväskylä University. Higher Education Management, 10(2), 7-29.

van Esch, W. (2005). Prestatiesturing onderwijsinstellingen bve. In J. Biessen, F. Ebbens, W. van Esch, R. Kleuskens \& T. Thielen (Eds.), Naar een Flexibel Organisatieregime in ROC's. Deel 2: Praktijkverkenningen. 's-Hertogenbosch: CINOP.

Vincent Lancrin, S. (2007). The 'crises' of public higher education: A comparative perspective. Research \& Occational Paper Series: CSHE.18.07.

Weick, K. E. (1976). Educational organizations as loosely coupled systems. Administrative Science Quarterly, 21, 1-19.

Ylijoki, O.-H. (2003). Entangled in academic capitalism? A case-study on changing ideals and practices of university research. Higher Education, 45, 307-335. 